\title{
Gladiolus production and nutritional status as a function of silicon application to the substrate ${ }^{1}$
}

\author{
Maristela Pereira Carvalho-Zanão ${ }^{2}$, Fabíola Villa² ${ }^{2}$ Luiz Antônio Zanão Júnior ${ }^{3}$
}

\begin{abstract}
Gladiolus is among the most traditional and important cut flowers in Brazil. Silicon (Si) is an element that has increased the production and quality of some ornamental plants. This study aimed at evaluating the production and nutritional status of gladiolus cultivars under greenhouse conditions, according to the $\mathrm{Si}$ doses applied to the substrate. The experimental design was randomized blocks, in a $3 \times 4$ factorial scheme, being three gladiolus cultivars ('White Friendship', 'Rose Friendship' and 'Red Beauty') and four Si doses $\left(0 \mathrm{mg} \mathrm{dm}^{-3}, 150 \mathrm{mg} \mathrm{dm}^{-3}, 300 \mathrm{mg} \mathrm{dm}^{-3}\right.$ and $600 \mathrm{mg} \mathrm{dm}^{-3}$ ), with five replicates. Morphological traits and leaf $\mathrm{Si}$, macro and micronutrients were evaluated. 'White Friendship' and 'Red Beauty' developed taller plants, with a higher diameter and spikes heavier and longer than 'Rose Friendship'. The order of leaf nutrient concentrations for all the cultivars evaluated was the same $(\mathrm{K}>\mathrm{N}>\mathrm{Ca}>\mathrm{Mg}>\mathrm{S}>$ $\mathrm{P}>\mathrm{Fe}>\mathrm{Mn}>\mathrm{B}>\mathrm{Zn}>\mathrm{Cu}$ ), with all of them being classified as Si non-accumulators. Neither the evaluated morphological variables, nor the uptake of the nutrients $\mathrm{N}, \mathrm{P}, \mathrm{K}, \mathrm{Ca}, \mathrm{Mg}, \mathrm{S}, \mathrm{B}$, $\mathrm{Cu}, \mathrm{Fe}, \mathrm{Mn}$ and $\mathrm{Zn}$, were affected by the Si supplementation, suggesting that the addition of Si to the substrate does not enhance the gladiolus production.
\end{abstract}

KEYWORDS: Gladiolus $x$ grandiflorus Hort.; ornamental plants; floriculture.

\section{INTRODUCTION}

Gladiolus (Gladiolus x grandiflorus Hort.) is a bulbous herbaceous plant from tropical to subtropical climate. This ornamental crop is used in landscaping and gardening, cut-flower decorations and commercial production of bulbs for the Brazilian market and for exporting (Barbosa 2011). It is an herbaceous plant with short life cycle and well adapted to Brazilian climatic conditions. Because of that, the production costs are relatively low, with a rapid return on investments.

\section{RESUMO}

Produção e estado nutricional de gladíolos em função da aplicação de silício ao substrato

O gladíolo encontra-se entre as mais tradicionais e importantes flores de corte, no Brasil. O silício (Si) é um elemento que tem aumentado a produção e qualidade de algumas plantas ornamentais. Objetivou-se avaliar a produção e o estado nutricional de cultivares de gladíolo em ambiente protegido, em função da aplicação de $\mathrm{Si}$ ao substrato. O delineamento experimental utilizado foi o de blocos ao acaso, em esquema fatorial $3 \times 4$, sendo três cultivares de gladíolo ('White Friendship', 'Rose Friendship' e 'Red Beauty') e quatro doses de $\mathrm{Si}\left(0 \mathrm{mg} \mathrm{dm}{ }^{-3}, 150 \mathrm{mg} \mathrm{dm}^{-3}\right.$, $300 \mathrm{mg} \mathrm{dm}^{-3}$ e $600 \mathrm{mg} \mathrm{dm}^{-3}$ ), com cinco repetições. Foram avaliadas características fitotécnicas, além dos teores foliares de $\mathrm{Si}$, macro e micronutrientes. 'White Friendship' e 'Red Beauty' produziram plantas mais altas, com maior diâmetro e hastes florais mais compridas e mais pesadas do que 'Rose Friendship'. A ordem do teor de nutrientes nas folhas das três cultivares foi a mesma $(K>N>$ $\mathrm{Ca}>\mathrm{Mg}>\mathrm{S}>\mathrm{P}>\mathrm{Fe}>\mathrm{Mn}>\mathrm{B}>\mathrm{Zn}>\mathrm{Cu}$ ), sendo todas elas classificadas como não acumuladoras de Si. A aplicação de Si não influenciou nenhuma variável fitotécnica avaliada e nem a absorção dos nutrientes $\mathrm{N}, \mathrm{P}, \mathrm{K}, \mathrm{Ca}, \mathrm{Mg}, \mathrm{S}, \mathrm{B}, \mathrm{Cu}, \mathrm{Fe}, \mathrm{Mn}$ e Zn, sugerindo que a adição de Si ao substrato não aumenta a produção de gladíolos.

PALAVRAS-CHAVE: Gladiolus $x$ grandiflorus Hort.; plantas ornamentais; floricultura.

According to the classical definition of essentiality, silicon $(\mathrm{Si})$ is not considered essential for plant nutrition. Nevertheless, it is often applied to crops because it provides several beneficial effects, such as upright leaves with higher photosynthetic capacity, increased chlorophyll content, reduced transpiration and loss of water, increased mechanical resistance of tissues and better resistance to diseases and pests (Epstein \& Bloom 2005).

Silicon is absorbed by plants as silicic acid $\left(\mathrm{H}_{4} \mathrm{SiO}_{4}\right)$ and translocated via xylem. It is mostly accumulated in areas of maximum transpiration, 
such as leaves, trichomes and spines, in the form of hydrated amorphous silica $\left(\mathrm{SiO}_{2} \cdot n \mathrm{H}_{2} \mathrm{O}\right)$, which prevents or reduces its mobility in the phloem (Currie \& Perry 2007, Taiz \& Zeiger 2013).

Silicon supplementation to composite substrates that contain little available $\mathrm{Si}$, such as organic and sand substrates, is reported to have positive effects on plants (Zanão Júnior et al. 2013). The main positive effects also include flowers with better quality and greater longevity (Jana \& Jeong 2014). Carvalho et al. (2013) found that the application of Si to the Dendrobium nobile orchid increased flower production and longevity. Ornamental plants, such as aster, clove, chrysanthemum, geranium, sunflower, petunia, rose, vinca and zinnia, accumulate $\mathrm{Si}$ in their tissues in amounts ranging 0.21-32.8 $\mathrm{g} \mathrm{kg}^{-1}$, depending on the species (Carvalho et al. 2009, Hogendorp et al. 2012, Zanão Júnior et al. 2013, Park et al. 2016). Beneficial effects of supplemental Si have been observed in many of these species, and these effects vary and strongly depend on the species, and even the cultivar (Jana \& Jeong 2014, Park et al. 2016)

Many substrates for ornamental plants contain very low levels of plant-available Si. Therefore, Si supplementation provides several benefits for the plants, such as those related to structural functions in plant architecture and water stress, from which gladiolus could benefit, since substrates for greenhouse cultivation of this crop often contain little soluble Si.

This study aimed at evaluating the effects of $\mathrm{Si}$ on the morphological traits and nutrient concentrations of three gladiolus cultivars ('White Friendship', 'Rose Friendship' and 'Red Beauty') grown in a greenhouse.

\section{MATERIAL AND METHODS}

The experiment was conducted from April to August 2014, in a greenhouse located in the western region of the Paraná State, Brazil (24\%33'S and $\left.54^{\circ} 31^{\prime} \mathrm{W}\right)$. Daily average temperature was $30.2^{\circ} \mathrm{C}$, with average minimum of $22.3{ }^{\circ} \mathrm{C}$ and maximum of $33.2{ }^{\circ} \mathrm{C}$.

The experimental design was randomized blocks, in a $3 \times 4$ factorial scheme, with three gladiolus cultivars ('White Friendship', 'Rose Friendship' and 'Red Beauty') and four Si doses $\left(0 \mathrm{mg} \mathrm{dm}^{-3}\right.$, $150 \mathrm{mg} \mathrm{dm}^{-3}, 300 \mathrm{mg} \mathrm{dm}^{-3}$ and $\left.600 \mathrm{mg} \mathrm{dm}^{-3}\right)$, with four replications. Each experimental unit consisted of a pot with two plants.

The 'White Friendship' and 'Rose Friendship' cultivars have an early cycle, while 'Red Beauty' has an intermediate cycle. 'Red Beauty' displays red petals, 'White Friendship' white petals, and 'Rose Friendship' pink petals.

Commercial corms (Premium Seeds, Brazil) with a perimeter of $14-16 \mathrm{~cm}$ were used. The corms were planted at $7 \mathrm{~cm}$ deep, in polyethylene pots containing $12 \mathrm{dm}^{3}$ of a mixture of Red Oxisol clay + fine washed sand + coconut shell fiber, in the proportion of 1:2:0.5 (v/v/v). The concentration of soluble $\mathrm{Si}$ in the substrate was $2 \mathrm{mg} \mathrm{dm}^{3}$, as determined by the colorimetric method, using $\mathrm{CaCl}_{2}$ as an extractor, and according to the methodology described by Korndörfer et al. (2004). At mixing, the substrate was amended with $100 \mathrm{mg} \mathrm{dm}^{-3}$ of $\mathrm{P}_{2} \mathrm{O}_{5}$, using single superphosphate $\left(18 \%\right.$ of $\mathrm{P}_{2} \mathrm{O}_{5}$ and $8 \%$ of $\mathrm{S}$ ).

Potassium silicate $\left(\mathrm{K}_{2} \mathrm{SiO}_{3}\right)$, containing $120 \mathrm{gkg}^{-1}$ of $\mathrm{Si}$ and $150 \mathrm{~g} \mathrm{~kg}^{-1}$ of $\mathrm{K}_{2} \mathrm{O}$, was used as a source of Si. Untreated plants and plants treated with $150 \mathrm{mg} \mathrm{dm}^{-3}$ and $300 \mathrm{mg} \mathrm{dm}^{-3}$ of Si received $\mathrm{KCl}$ to balance $\mathrm{K}$ among treatments. Thus, all treatments received $625 \mathrm{mg} \mathrm{dm}^{-3}$ of $\mathrm{K}$. The $\mathrm{pH}$ of the application solution was adjusted to 6.0, with $\mathrm{HCl} 1 \mathrm{~mol} \mathrm{~L}^{-1}$. Each cultivar received half of the Si dose at 15 days after emergence (DAE) and the other half one week later, via fertigation.

Fertilizer applications were carried out at 10, 17,21 and $30 \mathrm{DAE}$, by applying $200 \mathrm{~mL}$ of a nutrient solution, which contained the following salts: $\mathrm{NH}_{4} \mathrm{NO}_{3}$, $\mathrm{CO}\left(\mathrm{NH}_{2}\right)_{2}, \mathrm{MgSO}_{4} .7 \mathrm{H}_{2} \mathrm{O}, \mathrm{H}_{3} \mathrm{BO}_{3}, \mathrm{CuSO}_{4} .5 \mathrm{H}_{2} \mathrm{O}$, $\mathrm{FeSO}_{4} \cdot 7 \mathrm{H}_{2} \mathrm{O}, \mathrm{MnCl}_{2} \cdot 4 \mathrm{H}_{2} \mathrm{O},\left(\mathrm{NH}_{4}\right)_{6} \mathrm{Mo}_{7} \mathrm{O}_{24} \cdot 4 \mathrm{H}_{2} \mathrm{O}$ and $\mathrm{ZnSO}_{4} .7 \mathrm{H}_{2} \mathrm{O}$. The following are the total amounts of nutrients applied $\left(\mathrm{mg} \mathrm{dm}^{-3}\right): \mathrm{N}=160 ; \mathrm{S}=60 ; \mathrm{Mg}=$ $60 ; \mathrm{B}=1 ; \mathrm{Cu}=1.5 ; \mathrm{Fe}=2 ; \mathrm{Mn}=3.5 ; \mathrm{Mo}=0.2$; and $\mathrm{Zn}=5$.

Tillers were eliminated during the experiment, and there was no need to control pests and diseases. Plants were irrigated manually in the morning on a daily basis until the yellowing of the leaves, which coincided with the maturation of corms and cormels. The substrate weighing method was used to determine the field capacity of soil in the pots, which was maintained at approximately $80 \%$ (Porto et al. 2014).

Morphological evaluations were carried out using the phenological scale for gladiolus proposed by Schwab et al. (2015a). The following traits were 
evaluated: plant height $(\mathrm{cm})$, number of days until spike harvest, spike length $(\mathrm{cm})$, number of florets per spike, floret diameter $(\mathrm{cm})$, stem diameter $(\mathrm{cm})$, dry mass of leaves and spikes $\left(\mathrm{g} \mathrm{plant}^{-1}\right)$, and leaf nutrient and silicon concentrations.

The plant height, number of days until spike harvest, stem diameter, and leaf nutrient and silicon concentrations were evaluated at the R2 phenological stage, when the first three florets on the spike presented the color of the petals. Plant height was measured from the substrate line to the tip of the spike. The marketable harvest point of the spike was the number of days between corm planting and the R2 stage. Stem diameter at the lowest floret was measured with a digital caliper (two measurements were made per stem).

Nutrient and Si concentrations were determined in the two most mature leaves from each plant. Leaves were collected and washed in distilled water, packed in kraft paper bags and dried in a forced-air oven for $72 \mathrm{~h}$, at $65^{\circ} \mathrm{C}$, until constant mass. They were then weighed on a semi-analytical scale to determine dry matter and subsequently ground in a Wiley-type mill with a $0.84 \mathrm{~mm}$ screen. The material was mineralized by a mixture of nitric and perchloric acids $\left(3: 1 \mathrm{v} \mathrm{v}^{-1}\right)$. Concentrations of $\mathrm{Ca}, \mathrm{Mg}, \mathrm{Cu}, \mathrm{Fe}, \mathrm{Mn}$ and $\mathrm{Zn}$ were determined by atomic absorption spectrophotometry; $\mathrm{K}$ by flame emission photometry; $\mathrm{S}$ by turbidimetry; and $\mathrm{P}$ by colorimetry. To determine $\mathrm{N}$ concentrations, samples were mineralized with sulfuric acid, according to the semi-micro Kjeldahl method. Concentrations of $\mathrm{B}$ were determined by the Azomethine-H colorimetric method, after the incineration of the samples. Concentrations of $\mathrm{Si}$ were determined by the alkaline digestion method and dosing by the colorimetric method (Korndörfer et al. 2004).
The floret diameter of the lowest two florets on the spike was measured with digital calipers at the R3 stage, when the corolla of the first floret at the bottom of the spike is open, with visible anthers. The spike length and number of florets per spike were determined at the R3.6 stage, when half of the florets senesced. Spike length was measured from the lowest floret to the tip of the spike.

At the R6 stage, when all parts of the plant above the ground senesced, the leaves and spike (composed of the stem and florets) were separated and packed into kraft paper bags. The material was then dried in a forced-air oven for $72 \mathrm{~h}$, at $65^{\circ} \mathrm{C}$, until constant mass. After this period, the material was weighed on a semi-analytical scale, to record the dry matter. The mass of the leaf dry matter obtained at R2 was added to that obtained at R6, to calculate the total leaf dry matter yield.

Data were submitted to analysis of variance, using the statistical software Assistat (Silva \& Azevedo 2016). Averages for the cultivars were compared by the Tukey test at $5 \%$, and the effect of Si doses by regression analysis. Correlation coefficients were tested at $1 \%$ by the $t$-test.

\section{RESULTS AND DISCUSSION}

As no significant effect of interaction between Si doses and cultivars was observed, the results are discussed separately for each factor.

The plant height, spike length, number and diameter of florets on the spike and leaf and spike dry matter yield were higher for 'White Friendship' and 'Red Beauty' than for 'Rose Friendship' (Table 1).

In gladiolus, plant height corresponds to the length of the stem, and the marketable rates

Table 1. Plant height, days to spike harvest, spike length, florets per spike, floret diameter, stem diameter and leaf and spike dry matter yield of gladiolus cultivars grown in pots.

\begin{tabular}{|c|c|c|c|c|}
\hline \multirow{2}{*}{ Trait } & \multicolumn{3}{|c|}{ Cultivar } & \multirow{2}{*}{$\mathrm{CV}(\%)$} \\
\hline & 'White Friendship' & 'Rose Friendship' & 'Red Beauty' & \\
\hline Plant height $(\mathrm{cm})$ & $139.01 \mathrm{a}^{*}$ & $126.08 \mathrm{~b}$ & $148.78 \mathrm{a}$ & 10.11 \\
\hline Days to spike harvest & $66.67 \mathrm{~b}$ & $63.10 \mathrm{~b}$ & $92.45 \mathrm{a}$ & 12.72 \\
\hline Spike length $(\mathrm{cm})$ & $53.09 \mathrm{a}$ & $42.56 \mathrm{~b}$ & $52.13 \mathrm{a}$ & 11.48 \\
\hline Florets per spike & $14.10 \mathrm{a}$ & $12.27 \mathrm{~b}$ & $13.72 \mathrm{a}$ & 10.27 \\
\hline Floret diameter $(\mathrm{cm})$ & $9.85 \mathrm{a}$ & $9.71 \mathrm{a}$ & $9.64 \mathrm{a}$ & 6.88 \\
\hline Stem diameter $(\mathrm{cm})$ & $1.00 \mathrm{a}$ & $0.88 \mathrm{~b}$ & $1.02 \mathrm{a}$ & 7.21 \\
\hline Leaf dry matter yield (g plant ${ }^{-1}$ ) & $3.74 \mathrm{a}$ & $3.05 \mathrm{~b}$ & $3.90 \mathrm{a}$ & 9.83 \\
\hline Spike dry matter yield $\left(\mathrm{g}\right.$ plant $\left.{ }^{-1}\right)$ & $2.02 \mathrm{a}$ & $1.58 \mathrm{~b}$ & $2.16 \mathrm{a}$ & 9.33 \\
\hline
\end{tabular}

* Averages followed by the same letter in each line do not differ by the Tukey test $(\mathrm{p}<0.05)$. 
of "average", "long" and "extra" are based on this trait, as well as on stem diameter (Tombolato et al. 2010). According to this classification, spikes of 'White Friendship' and 'Red Beauty' were rated as "extra", being over $110 \mathrm{~cm}$ long, with a minimum stem diameter of $1.0 \mathrm{~cm}$. 'Rose Friendship' produced stems classified as "long", not because of the spike length (above $110 \mathrm{~cm}$ ), but due to the stem diameter, which was between $1 \mathrm{~cm}$ and $0.8 \mathrm{~cm}$.

All three cultivars produced marketable stem and spike length. According to Schwab et al. (2015b), the proportion of the length of the spike to the length of the stem is aesthetically pleasing when above $40 \%$. 'White Friendship' and 'Red Beauty', with stems classified as "extra" $(110 \mathrm{~cm})$ and spike length of $53.09 \mathrm{~cm}$ and $52.13 \mathrm{~cm}$, reached proportions of $48 \%$ and $47 \%$, respectively. In 'Rose Friendship', with stems classified as "long" $(90 \mathrm{~cm})$ and spike length of $42.56 \mathrm{~cm}$, this proportion was $47 \%$.

The number of florets per spike was, on average, 14.1, 12.3 and 13.7, respectively for 'White Friendship', 'Rose Friendship' and 'Red Beauty' (Table 1). According to Paiva et al. (2012), the number of florets per spike may range from 8 to 18 . Porto et al. (2012), studying the fertilization of the 'White Friendship' gladiolus, observed 12 to 14 florets per spike. Ruppenthal \& Castro (2005), evaluating the effects of different sources of fertilization (mineral and organic) on 'Red Beauty', found, on average, 15.8 florets per spike.

The number of days to spike harvest was lower for the 'White Friendship' and 'Rose Friendship' than for 'Red Beauty' (Table 1). 'White Friendship' and 'Rose Friendship' had a short cycle of approximately 67 and 63 days, respectively, while 'Red Beauty' had a median cycle of approximately 92 days. According to Paiva et al. (2012) and Barbosa (2011), such cycles are typical for these cultivars.

Stem diameter was larger in 'Red Beauty' $(1.02 \mathrm{~cm})$ and 'White Friendship' $(1.00 \mathrm{~cm})$ than in 'Rose Friendship' $(0.88 \mathrm{~cm})$ (Table 1$)$. This variable, whose minimum value should be $0.5 \mathrm{~cm}$, indirectly indicates the strength of the stem. There were no broken stems in this trial.

Floret diameter did not differ among cultivars, being, on average, $9.73 \mathrm{~cm}$ (Table 1). Thus, according to the classification proposed by Sheela (2008), florets were rated as "decorative", i.e., between $8.9 \mathrm{~cm}$ and $11.4 \mathrm{~cm}$ in diameter.

The dry matter yield of spikes and stems in 'White Friendship' and 'Red Beauty' were higher than in 'Rose Friendship', since they produced bigger plants with bigger spikes and thicker stems.

In the present study, $\mathrm{Si}$ additions to the substrate did not influence any of the morphological traits evaluated (Table 2). However, the Si fertilization of some species, such as gerbera, sunflower, rose, zinnia and phalaenopsis orchid, has been reported to improve the yield and quality of flowers. These species are considered Si accumulators (Kamenidou et al. 2008, 2009 and 2010, Vendrame et al. 2010, Zanão Júnior et al. 2013).

The response to Si supplementation mainly depends on the amount of Si the plant takes up and the amount of Si that is available in the substrate. Carvalho-Zanão et al. (2012) did not observe any significant response of chrysanthemum to supplemental Si. Mattson \& Leatherwood (2010), evaluating 21 species of flowers, found that, among these species, begonia, petunia, geranium, impatiens and vinca did not present any significant morphological response to the application of Si. In

Table 2. Plant height, days to spike harvest, spike length, florets per spike, floret diameter, stem diameter and leaf and spike dry matter yield, as a function of Si doses applied to the substrate of potted gladiolus.

\begin{tabular}{|c|c|c|c|c|c|}
\hline \multirow{2}{*}{ Trait } & \multicolumn{4}{|c|}{ Si dose $\left(\mathrm{mg} \mathrm{L}^{-1}\right)$} & \multirow{2}{*}{ Equation } \\
\hline & 0 & 150 & 300 & 600 & \\
\hline Plant height $(\mathrm{cm})$ & 135.93 & 137.06 & 138.33 & 140.51 & $\hat{y}=\bar{y}=137.11^{\text {ns }}$ \\
\hline Days to spike harvest & 74.50 & 73.20 & 74.30 & 74.30 & $\hat{y}=\bar{y}=74.08^{\mathrm{ns}}$ \\
\hline Spike length $(\mathrm{cm})$ & 47.68 & 48.38 & 50.84 & 50.14 & $\hat{\mathrm{y}}=\overline{\mathrm{y}}=49.26^{\mathrm{ns}}$ \\
\hline Florets per spike & 13.03 & 13.00 & 13.83 & 13.60 & $\hat{y}=\bar{y}=13.37^{\mathrm{ns}}$ \\
\hline Floret diameter $(\mathrm{cm})$ & 9.95 & 9.56 & 9.78 & 9.64 & $\hat{y}=\bar{y}=9.73^{\mathrm{ns}}$ \\
\hline Stem diameter $(\mathrm{cm})$ & 0.98 & 0.95 & 0.98 & 0.96 & $\hat{\mathrm{y}}=\overline{\mathrm{y}}=0.95^{\mathrm{ns}}$ \\
\hline Leaf dry matter yield (g plant $\left.{ }^{-1}\right)$ & 3.52 & 3.55 & 3.59 & 3.59 & $\hat{\mathrm{y}}=\overline{\mathrm{y}}=3.56^{\mathrm{ns}}$ \\
\hline Spike dry matter yield $\left(\mathrm{g}\right.$ plant $\left.{ }^{-1}\right)$ & 1.86 & 1.85 & 1.97 & 2.01 & $\hat{\mathrm{y}}=\overline{\mathrm{y}}=1.93^{\mathrm{ns}}$ \\
\hline
\end{tabular}

ns Not significant by the $t$-test $(\mathrm{p}<0.05)$. 
this study, the low availability of Si in the substrate and the lack of response to Si supplementation show that gladiolus has little sensitivity to $\mathrm{Si}$ fertilization.

'White Friendship' and 'Rose Friendship' presented a concentration of leaf N, P, K, Mg, B and Zn higher than 'Red Beauty'. On the other hand, leaf concentrations of $\mathrm{Fe}$ and $\mathrm{Mn}$ were the highest ones in 'Rose Friendship'. The concentrations of $\mathrm{Ca}, \mathrm{Cu}$ and $\mathrm{S}$ did not differ among the cultivars (Table 3 ).

Different nutrient demands by cultivars of the same species were observed by Villas Bôas et al. (2008) in rose, by Ludwig et al. (2013) in gerbera and by Ferreira et al. (2012) in chrysanthemum. According to Horn et al. (2006) and Rengel \& Damon (2008), this difference is due to genetic characteristics and is caused by the variation in the kinetic parameters of nutrient uptake and morphological differences of the root system.

Average leaf concentrations of $\mathrm{N}, \mathrm{P}, \mathrm{K}, \mathrm{Ca}$, $\mathrm{Mg}$ and $\mathrm{S}\left(\mathrm{g} \mathrm{kg}^{-1}\right)$ were, respectively, as it follows: 40.72, 3.64, 43.03, 14.38, 4.26 and 3.82 for 'White Friendship'; 41.84, 3.78, 45.29, 15.91, 4.47 and 3.90 for 'Rose Friendship'; 36.64, 3.30, 40.65, 14.62, 3.57 and 3.39 for 'Red Beauty'. Regarding the micronutrients $\mathrm{B}, \mathrm{Cu}, \mathrm{Fe}, \mathrm{Mn}$ and $\mathrm{Zn}$, their mean leaf concentrations $\left(\mathrm{mg} \mathrm{kg}^{-1}\right)$ were: $54.31,10.10$, 79.75, 62.87 and 34.06 for 'White Friendship'; 55.93, 10.54, 115.41, 97.97 and 35.52 for 'Rose Friendship'; $52.88,10.28,74.56,58.28$ and 31.00 for 'Red Beauty' (Table 3). According to Mills \& Jones Júnior (1996), all nutrient concentrations observed in this study were adequate for gladiolus.
The decreasing order of leaf macronutrient concentrations $\left(\mathrm{g} \mathrm{kg}^{-1}\right)$ in all three cultivars was the same: $\mathrm{K}>\mathrm{N}>\mathrm{Ca}>\mathrm{Mg}>\mathrm{S}>\mathrm{P}$. Regarding micronutrients, the decreasing order of leaf concentrations ( $\mathrm{mg} \mathrm{kg}^{-1}$ ) was also the same: $\mathrm{Fe}>$ $\mathrm{Mn}>\mathrm{B}>\mathrm{Zn}>\mathrm{Cu}$. Woltz (1954) found that the decreasing order of macronutrients in the 'Elisabeth The Queen' gladiolus was $\mathrm{K}>\mathrm{N}>\mathrm{Ca}>\mathrm{P}>\mathrm{Mg}$, while the order of micronutrients was $\mathrm{Fe}>\mathrm{Mn}>\mathrm{Cu}$. Haag et al. (1970) found that the 'Itapetininga' gladiolus presented the following order of leaf macronutrients at flowering: $\mathrm{K}>\mathrm{N}>\mathrm{Ca}>\mathrm{P}>\mathrm{S}>\mathrm{Mg}$. In the case of micronutrients, the order was the same as in the present study. Ruppenthal \& Castro (2005), evaluating different effects of organic and chemical fertilization of the 'Red Beauty' gladiolus, found that the decreasing order of leaf nutrient concentrations was $\mathrm{K}>\mathrm{Ca}>\mathrm{Mg}>\mathrm{P}>\mathrm{Fe}>\mathrm{Cu}>\mathrm{Zn}>\mathrm{Mn}$.

There were differences of Si uptake among cultivars: 'White Friendship' demonstrated the highest concentration $\left(0.45 \mathrm{~g} \mathrm{~kg}^{-1}\right)$, followed by 'Rose Friendship' $\left(0.38 \mathrm{~g} \mathrm{~kg}^{-1}\right)$ and 'Red Beauty' $\left(0.37 \mathrm{~g} \mathrm{~kg}^{-1}\right)$ (Table 3). Carvalho-Zanão et al. (2012) also observed genotypic differences regarding the uptake of $\mathrm{Si}$ in chrysanthemum and Zanão Júnior et al. (2013) in roses. According to Epstein (1999), Si concentrations in plants generally range $0.1-100 \mathrm{~g} \mathrm{~kg}^{-1}$ and, in plants known as $\mathrm{Si}$ accumulators, such as rice, it may be higher than that of macronutrients $\left(>100 \mathrm{~g} \mathrm{~kg}^{-1}\right)$.

According to the classification proposed by Ma et al. (2001), all three cultivars were classified as non-accumulators of $\mathrm{Si}$, as concentrations of this element in leaves were less than $5 \mathrm{~g} \mathrm{~kg}^{-1}$.

Table 3. Nitrogen, phosphorus, potassium, calcium, magnesium, sulfur, boron, copper, iron, manganese, zinc and silicon concentrations in leaves of gladiolus cultivars grown in pots.

\begin{tabular}{|c|c|c|c|c|}
\hline \multirow{2}{*}{ Leaf content } & \multicolumn{3}{|c|}{ Cultivar } & \multirow{2}{*}{$\mathrm{CV}(\%)$} \\
\hline & 'White Friendship' & 'Rose Friendship' & 'Red Beauty' & \\
\hline $\mathrm{N}\left(\mathrm{g} \mathrm{kg}^{-1}\right)$ & $40.72 \mathrm{a}^{*}$ & $41.84 \mathrm{a}$ & $36.64 \mathrm{~b}$ & 10.36 \\
\hline $\mathrm{P}\left(\mathrm{g} \mathrm{kg}^{-1}\right)$ & $3.64 \mathrm{a}$ & $3.78 \mathrm{a}$ & $3.30 \mathrm{~b}$ & 13.29 \\
\hline $\mathrm{K}\left(\mathrm{g} \mathrm{kg}^{-1}\right)$ & $43.03 \mathrm{a}$ & $45.29 \mathrm{a}$ & $40.65 \mathrm{~b}$ & 7.79 \\
\hline $\mathrm{Ca}\left(\mathrm{g} \mathrm{kg}^{-1}\right)$ & $14.38 \mathrm{a}$ & $15.91 \mathrm{a}$ & $14.62 \mathrm{a}$ & 7.43 \\
\hline $\operatorname{Mg}\left(\mathrm{g} \mathrm{kg}^{-1}\right)$ & $4.26 \mathrm{a}$ & $4.47 \mathrm{a}$ & $3.57 \mathrm{~b}$ & 7.94 \\
\hline $\mathrm{S}\left(\mathrm{g} \mathrm{kg}^{-1}\right)$ & $3.82 \mathrm{a}$ & $3.90 \mathrm{a}$ & $3.39 \mathrm{a}$ & 8.80 \\
\hline $\mathrm{B}\left(\mathrm{mg} \mathrm{kg}^{-1}\right)$ & $54.31 \mathrm{a}$ & $55.93 \mathrm{a}$ & $52.88 \mathrm{~b}$ & 5.83 \\
\hline $\mathrm{Cu}\left(\mathrm{mg} \mathrm{kg}{ }^{-1}\right)$ & $10.10 \mathrm{a}$ & $10.54 \mathrm{a}$ & $10.28 \mathrm{a}$ & 9.94 \\
\hline $\mathrm{Fe}\left(\mathrm{mg} \mathrm{kg}^{-1}\right)$ & $79.75 \mathrm{~b}$ & $115.41 \mathrm{a}$ & $74.56 \mathrm{~b}$ & 11.26 \\
\hline $\operatorname{Mn}\left(\mathrm{mg} \mathrm{kg}^{-1}\right)$ & $62.87 \mathrm{~b}$ & $97.97 \mathrm{a}$ & $58.28 \mathrm{~b}$ & 10.52 \\
\hline $\mathrm{Zn}\left(\mathrm{mg} \mathrm{kg}^{-1}\right)$ & $34.06 \mathrm{a}$ & $35.52 \mathrm{a}$ & $31.00 \mathrm{~b}$ & 12.32 \\
\hline $\mathrm{Si}\left(\mathrm{g} \mathrm{kg}^{-1}\right)$ & $0.45 \mathrm{a}$ & $0.38 \mathrm{~b}$ & $0.37 \mathrm{~b}$ & 9.36 \\
\hline
\end{tabular}

* Means followed by the same lowercase letter do not differ by the Tukey test $(\mathrm{p}<0.05)$. 
Table 4. Nitrogen, phosphorus, potassium, calcium, magnesium, sulfur, boron, copper, iron, manganese, zinc and silicon concentrations in leaves of gladiolus cultivated in pots, as a function of silicon applications to the substrate.

\begin{tabular}{|c|c|c|c|c|c|}
\hline \multirow{2}{*}{ Leaf content } & \multicolumn{4}{|c|}{ Si dose $\left(\mathrm{mg} \mathrm{L}^{-1}\right)$} & \multirow{2}{*}{ Equation } \\
\hline & 0 & 150 & 300 & 600 & \\
\hline $\mathrm{N}\left(\mathrm{g} \mathrm{kg}^{-1}\right)$ & 39.76 & 41.12 & 39.68 & 38.40 & $\hat{\mathrm{y}}=\overline{\mathrm{y}}=39.74^{\mathrm{ns}}$ \\
\hline $\mathrm{P}\left(\mathrm{g} \mathrm{kg}^{-1}\right)$ & 3.26 & 3.66 & 3.64 & 3.76 & $\hat{\mathrm{y}}=\overline{\mathrm{y}}=3.58^{\mathrm{ns}}$ \\
\hline $\mathrm{K}\left(\mathrm{g} \mathrm{kg}^{-1}\right)$ & 41.97 & 44.94 & 41.64 & 43.42 & $\hat{\mathrm{y}}=\overline{\mathrm{y}}=42.99^{\mathrm{ns}}$ \\
\hline $\mathrm{Ca}\left(\mathrm{g} \mathrm{kg}^{-1}\right)$ & 14.42 & 14.79 & 14.93 & 14.40 & $\hat{y}=\bar{y}=14.64^{\mathrm{ns}}$ \\
\hline $\operatorname{Mg}\left(\mathrm{g} \mathrm{kg}^{-1}\right)$ & 4.06 & 4.14 & 4.21 & 3.99 & $\hat{\mathrm{y}}=\overline{\mathrm{y}}=4.10^{\mathrm{ns}}$ \\
\hline $\mathrm{S}\left(\mathrm{g} \mathrm{kg}^{-1}\right)$ & 2.89 & 3.29 & 3.31 & 2.93 & $\hat{\mathrm{y}}=\overline{\mathrm{y}}=3.11^{\mathrm{ns}}$ \\
\hline $\mathrm{B}\left(\mathrm{mg} \mathrm{kg}^{-1}\right)$ & 58.94 & 54.34 & 58.94 & 55.27 & $\hat{y}=\bar{y}=56.87^{n s}$ \\
\hline $\mathrm{Cu}\left(\mathrm{mg} \mathrm{kg}^{-1}\right)$ & 75.11 & 68.13 & 63.05 & 65.32 & $\hat{y}=\bar{y}=67.90^{\mathrm{ns}}$ \\
\hline $\mathrm{Fe}\left(\mathrm{mg} \mathrm{kg}^{-1}\right)$ & 32.14 & 32.98 & 32.76 & 32.68 & $\hat{y}=\bar{y}=32.64^{\mathrm{ns}}$ \\
\hline $\operatorname{Mn}\left(\mathrm{mg} \mathrm{kg}^{-1}\right)$ & 70.09 & 71.45 & 78.15 & 72.48 & $\hat{y}=\bar{y}=73.04^{\mathrm{ns}}$ \\
\hline $\mathrm{Zn}\left(\mathrm{mg} \mathrm{kg}^{-1}\right)$ & 32.98 & 34.20 & 33.60 & 33.34 & $\hat{\mathrm{y}}=\overline{\mathrm{y}}=33.53^{\mathrm{ns}}$ \\
\hline $\mathrm{Si}\left(\mathrm{g} \mathrm{kg}^{-1}\right)$ & 0.29 & 0.35 & 0.40 & 0.55 & $\hat{\mathrm{y}}=0.19+0.083 * * \mathrm{x} ; \mathrm{R}^{2}=0.94$ \\
\hline
\end{tabular}

${ }^{\text {ns }}$ and $* *$ : Non-significant and significant at $1 \%$, by the $t$-test, respectively.

Silicon applications to the substrate did not affect the uptake of any macro or micronutrient, possibly because the cultivars did not absorb large amounts of Si. Changes in nutrient and $\mathrm{Al}$ uptake induced by $\mathrm{Si}$ applications were observed in Siaccumulating crops, mainly under biotic or abiotic stress conditions. Chen et al. (2000) stated that Si inhibits the uptake of $\mathrm{Al}, \mathrm{Mn}$ and $\mathrm{Na}$, and facilitates the uptake of $\mathrm{P}, \mathrm{Mg}, \mathrm{K}, \mathrm{Fe}, \mathrm{Cu}$ and $\mathrm{Zn}$.

In this trial, only leaf $\mathrm{Si}$ concentrations grew linearly with Si doses, because Si was added to the nutrient solution in a plant-available form (Table 4). Evaluating 21 ornamental species cultivated in a peatbased substrate and weekly fertilized with $100 \mathrm{mg} \mathrm{L}^{-1}$ of potassium silicate, Mattson \& Leatherwood (2010) found a $13-145 \%$ increase in the leaf Si concentration in + Si plants, relatively to $-\mathrm{Si}$ plants.

Although the plants absorbed Si linearly with the concentration of this element in the substrate, no effect was verified on the morphology of the plants. Probably, the low Si absorption may justify the lack of significant effect of this element. Even with the application of $600 \mathrm{mg} \mathrm{L}^{-1}$ of $\mathrm{Si}$, the leaves only presented contents of $0.55 \mathrm{~g} \mathrm{~kg}^{-1}$ of Si. With this low absorption rate and absence of effects on plant morphology, there are no subsidies for the recommendation of Si supplementation in the gladiolus crop. According to Carvalho-Zanão et al. (2012), for the benefits of Si to occur, it is necessary that the plant be an accumulator of this element. By evaluating the application of $\mathrm{Si}$ doses in three chrysanthemum cultivars, the authors verified the absorption of $\mathrm{Si}$ in small quantities, and that this absorption did not result in any effect on the morphological traits evaluated, including floral longevity.

\section{CONCLUSIONS}

1. The 'White Friendship' and 'Red Beauty' gladiolus cultivars produce taller plants, with longer spikes and thicker and heavier stems, than 'Rose Friendship';

2. The decreasing order of leaf nutrient concentrations in all three cultivars is the same: $\mathrm{K}>\mathrm{N}>\mathrm{Ca}>$ $\mathrm{Mg}>\mathrm{S}>\mathrm{P}>\mathrm{Fe}>\mathrm{Mn}>\mathrm{B}>\mathrm{Zn}>\mathrm{Cu}$;

3. All cultivars evaluated may be classified as $\mathrm{Si}$ non-accumulators;

4. Silicon additions to the substrate do not affect any morphological variable, or the uptake of $\mathrm{N}, \mathrm{P}, \mathrm{K}$, $\mathrm{Ca}, \mathrm{Mg}, \mathrm{S}, \mathrm{B}, \mathrm{Cu}, \mathrm{Fe}, \mathrm{Mn}$ and $\mathrm{Zn}$, in all the gladiolus cultivars evaluated, suggesting that $\mathrm{Si}$ fertilization may not enhance the gladiolus production.

\section{ACKNOWLEDGMENTS}

The authors thank the Coordenação de Aperfeiçoamento de Pessoal de Nível Superior (Capes), for the scholarship granted to the first author.

\section{REFERENCES}

BARBOSA, J. G. Palma-de-santa-rita (gladiolo): produção comercial de flores e bulbos. Viçosa: Ed. UFV, 2011. 
CARVALHO, M. P. et al. Silício melhora produção e qualidade do girassol ornamental em vaso. Ciência Rural, v. 39, n. 8, p. 2394-2399, 2009.

CARVALHO, P. R. et al. Efeito do silício na qualidade de flores de Dendrobium nobile (Orchidaceae). Semina: Ciências Agrárias, v. 34, n. 4, p. 1615-1622, 2013.

CARVALHO-ZANÃO, M. P. et al. Yield and shelf life of chrysanthemum in response to the silicon application. Horticultura Brasileira, v. 30, n. 3, p. 403-408, 2012.

CHEN, J. et al. Silicon: the estranged medium element. 2000. Available at: $<$ http://www.fngla.org/education-andresearch/research/reports/75/finalreport.pdf $>$. Access on: Jan. 24, 2017.

CURRIE, H. A.; PERRY, C. C. Silica in plants: biological, biochemical and chemical studies. Annals of Botany, v. 100, n. 7, p. 1383-1389, 2007.

EPSTEIN, E.; BLOOM, A. J. Mineral nutrition of plants: principles and perspectives. Sunderland: Sinauer Associates, 2005.

EPSTEIN, E. Silicon. Annual Review of Plant Physiology and Plant Molecular Biology, v. 50, n. 1, p. 641-664, 1999.

FERREIRA, L. D. B. et al. Acúmulo de macronutrientes em cultivares de crisântemo para vaso, em Goianira GO. Revista Brasileira de Ciências Agrárias, v. 7, n. 1, p. 9-16, 2012.

HAAG, H. P.; OLIVEIRA, G. D.; MATTOS, J. R. Nutrição mineral de plantas ornamentais: I. Absorção de nutrientes pela cultura de gladíolos. Anais da Escola Superior de Agricultura Luiz de Queiroz, v. 27, n. 1, p. 125-141, 1970.

HOGENDORP, B. K.; CLOYD, R. A.; SWIADER, J. M. Determination of silicon concentration in some horticultural plants. Hortscience, v. 47, n. 11, p. 15931595, 2012.

HORN, D. et al. Parâmetros cinéticos e morfológicos da absorção de nutrientes em cultivares de milho com variabilidade genética contrastante. Revista Brasileira de Ciência do Solo, v. 30, n. 1, p. 77-85, 2006.

JANA, S.; JEONG, B. R. Silicon: the most underappreciated element in horticultural crops. Trends in Horticultural Research, v. 4, n. 1, p. 1-19, 2014.

KAMENIDOU, S.; CAVINS, T. J.; MAREK, S. Evaluation of silicon as a nutritional supplement for greenhouse zinnia production. Scientia Horticulturae, v. 119, n. 3, p. 297-301, 2009.

KAMENIDOU, S.; CAVINS, T. J.; MAREK, S. Silicon supplements affect horticultural traits of greenhouseproduced ornamental sunflowers. Hortscience, v. 43, n. 1, p. 236-239, 2008.
KAMENIDOU, S.; CAVINS, T. J.; MAREK, S. Silicon supplements affect floricultural quality traits and elemental nutrient concentrations of greenhouse produced gerbera. Scientia Horticulturae, v. 123, n. 3, p. 390-394, 2010.

KORNDÖRFER, G. H.; PEREIRA, H. S.; NOLA, A. Análise de silício: solo, planta e fertilizante. Uberlândia: GPSi-ICIAG-UFU, 2004.

LUDWIG, F. et al. Absorção de nutrientes em cultivares de gérbera cultivada em vaso. Horticultura Brasileira, v. 31, n. 4, p. 622-627, 2013.

MA, J. F.; MIYAKE, Y.; TAKAHASHI, E. Silicon as a beneficial element for crop plants. In: DATNOFF, L. E.; SNYDER, G. H.; KORNDORFER, G. H. (Eds.). Silicon in agriculture. Dordrecht: Elsevier Science, 2001. p. 17-39.

MATTSON, N. S.; LEATHERWOOD, W. R. Potassium silicate drenches increase leaf silicon content and affect morphological traits of several floriculture crops grown in a peat-based substrate. HortScience, v. 45, n. 1, p. 4347, 2010.

MILLS, H. A.; JONES JÚNIOR, J. B. Plant analysis handbook II: a practical sampling, preparation, analysis and interpretation guide. Athens: MicroMacro, 1996.

PAIVA, P. D. O.; FERNANDES, K. D.; CERATTI, M. Gladíolo. In: PAIVA, P. D. O; ALMEIDA, E. F. A. (Orgs.). Produção de flores de corte. Lavras: UFLa, 2012. p. 449469.

PARK, Y. G. et al. Silicon and horticultural crops: evaluation of silicon uptake and deposition in floricultural plants. In: TRIPATHI, D. K. et al. (Org.). Silicon in plants: advances and future prospects. Boca Raton: CRC Press, 2016. p. 114-127.

PORTO, R. A. et al. Adubação nitrogenada no crescimento e produção de gladíolos em Latossolo Vermelho no Cerrado. Agroecossistemas, v. 4, n. 1, p. 2-11, 2012.

PORTO, R. A. et al. Effects of water replacement levels and nitrogen fertilization on growth and production of gladiolus in a greenhouse. Agricultural Water Management, v. 131, n. 1, p. 50-56, 2014.

RENGEL, Z.; DAMON, P. M. Crops and genotypes differ in efficiency of potassium uptake and use. Physiologia Plantarum, v. 133, n. 4, p. 624-636, 2008.

Ruppenthal, V.; CASTRO, A. M. C. Efeito do composto de lixo urbano na nutrição e produção de gladíolos. Revista Brasileira de Ciência do Solo, v. 29, n. 1, p. 145-150, 2005.

SCHWAB, N. T. et al. A phenological scale for the development of gladiolus. Annals of Applied Biology, v. 166, n. 3, p. 496-507, $2015 \mathrm{a}$. 
SCHWAB, N. T. et al. Parâmetros quantitativos de hastes florais de gladíolo conforme a data de plantio em ambiente subtropical. Pesquisa Agropecuária Brasileira, v. 50, n. 10, p. 902-911, 2015b.

SHEELA, V. L. Flowers for trade. New Delhi: New India Publishing Agency, 2008.

SILVA, F. A. S.; AZEVEDO, C. A. V. The Assistat software version 7.7 and its use in the analysis of experimental data. African Journal of Agricultural Research, v. 11, n. 39, p. 3733-3740, 2016.

TAIZ, L.; ZEIGER, E. Fisiologia vegetal. 5. ed. Porto Alegre: Artmed, 2013.

TOMBOLATO, A. F. C. et al. Bulbosas ornamentais no Brasil. Revista Brasileira de Horticultura Ornamental, v. 16, n. 2, p. 127-138, 2010.
VENDRAME, W.A. etal. Silicon fertilization affects growth of hybrid phalaenopsis orchid liners. Horttechnology, v. 20, n. 3, p. 603-607, 2010.

VILLAS BÔAS, R. L. et al. Exportação de nutrientes e qualidade de cultivares de rosas em campo e em ambiente protegido. Horticultura Brasileira, v. 26, n. 4, p. 515-519, 2008.

WOLTZ, S. S. Studies on the nutritional requirements of gladiolus. Florida Agricultural Experiment Station Journal Series, v. 296, n. 1, p. 330-335, 1954.

ZANÃO JÚNIOR, L. A. et al. Produção de rosas influenciada pela aplicação de doses de silício no substrato. Revista Brasileira de Ciência do Solo, v. 37, n. 6, p. 16111619, 2013. 